\title{
Studies of protein requirements of ruminants
}

\section{Nitrogen balance trials on two breeds of African cattle given diets adequate in energy and low in protein}

\author{
By R. C. ELLIOTT* aNd J. H. TOPPS \\ Department of Agriculture, University College of Rhodesia and \\ Nyasaland, Salisbury, S Rhodesia
}

(Received 4 March 1963-Revised 22 fuly 1963)

Herbage with a very low protein content forms the main diet of ruminants in many parts of Africa for several months of the year. This poor nutritional environment is the result of a seasonal distribution of the annual rainfall and is typical of conditions which prevail during the winter in the Federation of Rhodesia and Nyasaland. Here rain falls between November and April, green grazing is absent for the rest of the year except on marshy areas, and the mature standing grass has a protein content of $\mathrm{I}-3 \%$. Cattle lose weight during the dry season when kept under range conditions and by November they are emaciated unless hand-fed. With the advent of rains and subsequent growth of grass, cattle regain weight, but several weeks may elapse before the body losses, which occurred during the dry season, are recovered and net gains in weight result. For this reason it is the practical aim of many cattlemen to maintain the weight of their stock in the dry season, by giving a protein-rich food, so that the potential of grazing in the rainy season for live-weight gain can be fully exploited.

Because it is desirable economically to give the minimum amount of protein necessary to maintain body-weight, the protein requirement for maintenance of cattle is of special significance. An attempt to assess this requirement has been made and is the subject of this report.

Examination of the literature showed that the protein requirements for maintenance of beef cattle were ill-defined and invariably based on evidence obtained 25-30 years ago. Further, it was not illogical to assume that the protein needs of African cattle, which normally graze herbage low in protein, may be less than the recognized standards. It is possible that through natural selection some adaptation to the adverse nutritional conditions may have occurred. The recent work of Elliott ( $\left.196_{3}\right)$ supports this concept.

To ensure that a valid measure of the protein requirement for maintenance was obtained, the diets used during the trials had a high or adequate energy content (see Table 2). Concurrent work on the nitrogen metabolism of the cattle under trial, which involved the determination of the percentage distribution of $\mathrm{N}$ in the urine, has already been reported (Elliott \& Topps, 1963).

- Seconded from the Department of Research and Specialist Services, Federal Ministry of Agriculture. 


\section{EXPERIMENTAL}

Animals and experimental design. Twelve Africander steers and twelve Mashona steers (a local indigenous breed) were used. Both breeds are classified by Mason \& Maule (I960) as Sanga cattle and are indigenous to Southern Africa. Each breed comprised three groups of four animals aged approximately 1,2 and 3 years respectively. Four diets, with different crude-protein contents, were given to each group in the sequence $9 \%$ crude-protein diet, 7, I I and finally the $5 \%$ crude-protein diet. This factorial arrangement of treatments (two breeds $\times$ three ages $\times$ four protein levels) allowed any interactions between breed, age and $\mathrm{N}$ utilization to be determined statistically. Unfortunately, it did not allow first-order residual effects to be detected and eliminated.

Diets. The four diets were chosen to be approximately isocaloric. They consisted of $60 \%$ concentrates and $40 \%$ roughages. The crude-protein contents were 5 , 7,9 and $11 \%$, and this range was obtained by adjusting the relative amounts of

Table 1. Percentage composition of the diets of different crude. protein (CP) content

\begin{tabular}{lcccc}
\multicolumn{1}{c}{ Ingredient } & $5 \% \mathrm{CP}$ & $7 \% \mathbf{C P}$ & $9 \% \mathbf{C P}$ & II $\% \mathrm{CP}$ \\
Molasses & 9.8 & 9.8 & 9.8 & 9.8 \\
Cassava & 30.7 & 25.8 & 21.8 & 17.6 \\
Maize & 13.3 & 13.3 & 13.3 & 13.3 \\
Cottonseed cake & 0.4 & 5.3 & 9.3 & 13.5 \\
Lucerne hay & 8.9 & 8.9 & 8.9 & 8.9 \\
Rhodes grass hay & 35.6 & 35.6 & 35.6 & 35.6 \\
Bone meal & 0.89 & 0.89 & 0.89 & 0.89 \\
Salt & 0.44 & 0.44 & 0.44 & 0.44
\end{tabular}

In addition $25 \mathrm{~g}$ copper sulphate $\left(\mathrm{C}_{4} \mathrm{SO}_{4} .5 \mathrm{H}_{2} \mathrm{O}\right)$ and $0.5 \mathrm{~g}$ cobalt chloride $\left(\mathrm{CoCl}_{2} .6 \mathrm{H}_{2} \mathrm{O}\right)$ were added per ton.

cassava and cottonseed cake in the concentrate portion. The diets will be referred to from here on as the 5, 7, 9 and I $\%$ crude-protein (CP) diets. Their detailed composition is given in Table $I$.

The feeds were milled, mixed and cubed to obviate selection by the animals of the more acceptable components of the diet. The amount of food offered was related to individual body-weight and based on the finding of Blaxter, Wainman \& Wilson ( 1961 ) that the voluntary food intake of ruminants is directly related to $W^{0.73}, W$ being the body-weight. In this trial the weight of food offered (kg/day) was equal to 0.123 $W^{0 \cdot 73}$, when $W$ was expressed in $\mathrm{kg}$. In general, the diets were readily eaten and, except for the $5 \% \mathrm{cP}$ diet with which food refusals of some animals were appreciable, only very small amounts of waste were recorded. Access to water was provided at all times.

Methods. Each $\mathrm{N}$ balance trial consisted of a ro-day preliminary period followed by a 7 -day collection period. During the collection periods the cattle were housed in individual metabolism stalls which were constructed to allow the separate, quantitative collection of urine and faeces. The animals were fed twice daily with equal portions at 6.30 am and $4 \mathrm{pm}$. They were weighed at the beginning of each preliminary period 
and at the beginning and end of each collection period. Faeces were collected on a Polythene sheet and the urine into a Polythene bottle containing sufficient sulphuric acid to maintain the liquid at a $\mathrm{pH}$ of $2 \cdot 5-3^{\circ}$. After every feeding, the volumes of urine, acid and 'washing down' water were measured and the faeces weighed. Hundredth portions of each urine collection were combined separately for each animal and the combined samples stored at $0^{\circ}$. After thorough mixing two fiftieth portions of each faecal collection were weighed, one into a Polythene bag and stored at $-15^{\circ}$ and the other for dry-matter determination. Samples taken over the whole collection period were pooled for each steer. At the end of each collection period the composite samples of urine and frozen faeces were mixed and sampled for determination of $\mathrm{N}$.

The $\mathrm{N}$ contents of the food, food refusals, faeces and urine were determined by the macro-Kjeldahl procedure with a mercury catalyst. The dry-matter content of the food, food refusals and faeces was obtained by heating at $105^{\circ}$ to constant weight.

Table 2. Mean daily consumptions ( $\mathrm{g} / \mathrm{kg} \mathrm{W}^{0.73}$ ) of dry matter (DM) and digestible organic matter (DOM) in four rations by eight steers offered $123 \mathrm{~g} / \mathrm{kg} \mathrm{W}^{0.73 *}$

Crude-protein
content of
diet $(\%)$
5
7
9
II

$\begin{array}{rr}\text { DM } & \text { DOM } \\ 108 & 57.6 \\ 112 & 63.8 \\ 99 & 55.9 \\ 105 & 60.3\end{array}$

$\begin{array}{ll}\text { 2-year-old steers } \\ \text { DM } & \text { DOM } \\ \text { IO2 } & 52 \cdot 7 \\ \text { IO8 } & 59.2 \\ \text { II I } & 64.9 \\ 109 & 64.8\end{array}$

$\begin{array}{rr}\text { DM } & \text { DOM } \\ 103 & 56 \cdot 0 \\ 108 & 61 \cdot 1 \\ 97 & 55 \cdot 2 \\ 111 & 65 \cdot 2\end{array}$

- Brody's (1945) daily maintenance requirement for energy is approximately $35 \mathrm{~g}$ Dom/kg $W^{0.73}$.

\section{RESULTS}

Food consumption and protein content of rations. Although the diets were offered at a constant rate per $\mathrm{kg}$ metabolic body size, the consumption of the four diets reflected the steers' voluntary intake only when food was refused, which seldom occurred. Despite this limitation, a few trends may be noted from the mean intakes of the three age groups listed in Table 2. Dry-matter intake of the I- and 3-year-old animals was low when they were given the $9 \%$ CP diet, probably owing to these two balance trials being the first of the series when the animals were not accustomed to either the cubed diets or the routine handling procedure. In general, the intake of feed by the steers increased as the protein content of the diets was raised. This observation suggests that though consumption of these cubed diets was generally high, appetite was slightly reduced when the protein content was decreased.

Apparent digestibility of $N$. The values for the apparent digestibility of $\mathrm{N}$ were subjected to an analysis of covariance, but the differences between breeds and age groups were not significant. This finding was to be expected because differences in the digestive ability of individuals within a species are usually acknowledged to be very small.

There was a close relationship $(r=0.9745)$ between the total $\mathrm{N}$ consumed and that 
apparently digested. The two sets of values were related by the linear equation $Y=0.756 X-0.366$, where $X$ is the percentage of $\mathrm{N}$ and $Y$ the percentage of apparently digestible $\mathrm{N}$ in the dry matter of the feed. The constant 0.366 is an estimate of the metabolic faecal $\mathrm{N}(\mathrm{g})$ excreted/100 $\mathrm{g}$ dry matter consumed. This figure is lower than the value often accepted for ruminants of $0.5 \mathrm{~g} / 100 \mathrm{~g}$ dry food consumed (Maynard \& Loosli, 1956).

$N$ balance. In every $\mathrm{N}$ balance trial all twenty-four animals were in positive $\mathrm{N}$ balance, showing that, at the four levels of protein, $\mathrm{N}$ storage occurred irrespective of age or breed. The detailed $\mathrm{N}$ balance results are presented in Table 3 .

Table 3. Mean values $(g / 24 h)$ for intake, faecal excretion, urinary excretion, and retention of nitrogen for groups of four steers given four different diets

\begin{tabular}{|c|c|c|c|c|c|c|}
\hline \multirow{2}{*}{$\begin{array}{l}\text { Crude-protein } \\
\text { content of } \\
\text { diet }(\%)\end{array}$} & \multirow[b]{2}{*}{ Breed } & \multirow{2}{*}{$\begin{array}{c}\text { Age } \\
\text { (years) }\end{array}$} & \multirow[b]{2}{*}{ Intake } & \multicolumn{2}{|c|}{ Excretion } & \multirow[b]{2}{*}{ Retention } \\
\hline & & & & Faecal & Lrinary & \\
\hline \multirow[t]{5}{*}{5} & Mashona & I & $\begin{array}{l}49^{\circ} \\
60 \cdot 7\end{array}$ & $32 \cdot 9$ & 10.4 & 5.7 \\
\hline & & $\begin{array}{l}2 \\
3\end{array}$ & 749 & $\begin{array}{l}39 \cdot 0 \\
46 \cdot 1\end{array}$ & $\begin{array}{l}14.1 \\
16.3\end{array}$ & $\begin{array}{r}7 \cdot 6 \\
12 \cdot 5\end{array}$ \\
\hline & Africander & $\mathbf{I}$ & $58 \cdot 7$ & $39 \cdot 0$ & $12 \cdot 2$ & 7.5 \\
\hline & & 2 & $73^{\cdot 2}$ & $49^{\circ} 3$ & 16.5 & 74 \\
\hline & & 3 & $8 x \cdot 6$ & $51^{\circ} \cdot 0$ & $18 \cdot 7$ & $11 \cdot 9$ \\
\hline \multirow[t]{6}{*}{7} & Mashona & I & $65^{\circ}$ & $37 \cdot 7$ & $12 \cdot 2$ & 15.1 \\
\hline & & 2 & $8 r \cdot 7$ & $52 \cdot 4$ & $17 \cdot 1$ & $12 \cdot 2$ \\
\hline & & 3 & $87 \cdot 0$ & $53 \cdot 3$ & $19 \cdot 4$ & 143 \\
\hline & Africander & I & $73 \cdot 6$ & $47 \cdot 0$ & $16 \cdot 2$ & 10.4 \\
\hline & & 2 & $93 \cdot 6$ & $5^{6 \cdot 6}$ & 20.5 & $16 \cdot 5$ \\
\hline & & 3 & 100.7 & $62 \cdot 7$ & $23 \cdot I$ & 14.9 \\
\hline \multirow[t]{6}{*}{9} & Mashona & I & $71 \cdot 3$ & $36 \cdot 5$ & 15.6 & $19 \cdot 2$ \\
\hline & & 2 & $95 \cdot 4$ & $49 \cdot 7$ & $26 \cdot 2$ & $\times 9.5$ \\
\hline & & 3 & 102.4 & $52 \cdot 9$ & $26 \cdot 2$ & $23 \cdot 3$ \\
\hline & Africander & I & $87 \cdot 0$ & $47 \cdot 8$ & 20.2 & 19.0 \\
\hline & & 2 & 130.1 & $5^{8 \cdot 6}$ & $37 \cdot 3$ & $34 \cdot 2$ \\
\hline & & 3 & 123.7 & $60 \cdot 0$ & 30.8 & $32 \cdot 9$ \\
\hline \multirow[t]{6}{*}{ I I } & Mashona & I & $95 \cdot 2$ & $44 \cdot 6$ & $26 \cdot 7$ & 23.9 \\
\hline & & 2 & 125.0 & $5^{8.6}$ & $44 \cdot I$ & $22 \cdot 3$ \\
\hline & & 3 & $149 \cdot 6$ & 68.9 & $45^{\circ} 9$ & 34.8 \\
\hline & Africander & $\mathrm{I}$ & I 16.3 & $53^{\circ} 0$ & $36 \cdot 6$ & $26 \cdot 7$ \\
\hline & & 2 & $141^{\prime} 7$ & $68 \cdot 1$ & $49 \cdot 3$ & $24 \cdot 3$ \\
\hline & & 3 & 175.5 & $74 \cdot 1$ & $56 \cdot 5$ & 44.9 \\
\hline
\end{tabular}

No measurements were made of the small $\mathrm{N}$ losses in skin excretions and shed hair. Blaxter (1959) from an analysis of results of seventeen experiments calculated this loss to be $5 \pm 0.5 \mathrm{mg} \mathrm{N} / \mathrm{kg}$ metabolic body size. If this value is used, the mean daily additional loss of $\mathrm{N}$ would range from $0.275 \mathrm{~g}$ for the smallest steer (I-year-old Mashona) to $0.455 \mathrm{~g}$ for the largest (3-year-old Africander). All the animals had smooth, short coats so it is unlikely that the real loss would appreciably exceed these calculated values. Thus, even if this loss is taken into account, the finding that all animals were in positive $\mathrm{N}$ balance on the four rations remains valid.

In planning the experiment it was assumed that when the steers were given the rations with the two lowest protein contents a loss of protein from the body would 
probably result. If on the contrary a gain of body protein were to occur it would indicate that the animals had an unusually low maintenance requirement for protein.

Relationship between apparently digestible $N$ eaten and $N$ retention. For each steer the amount of $\mathrm{N}$ retained was closely related to the quantity of apparently digested

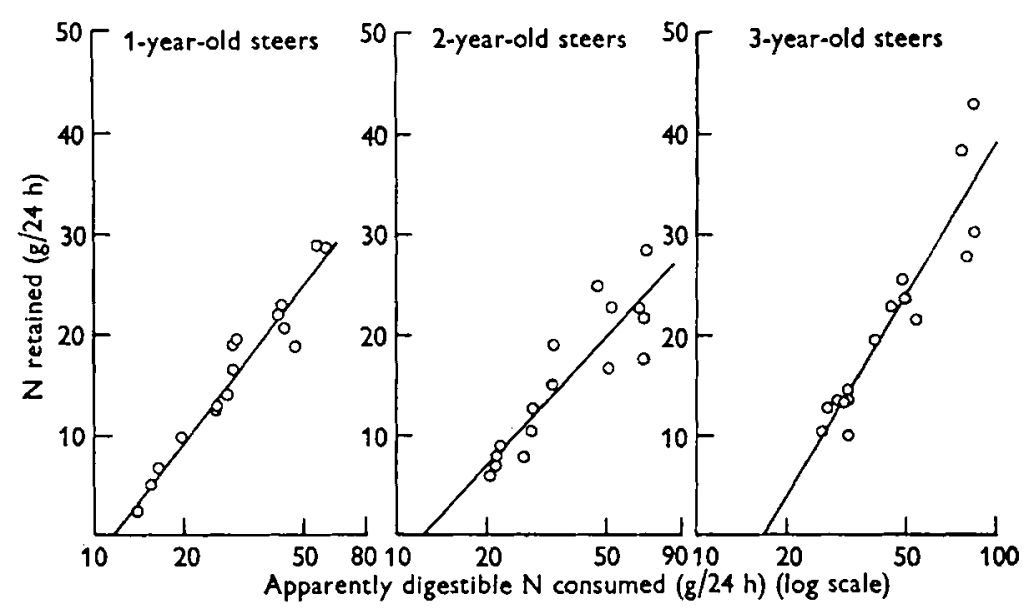

Fig. I. Nitrogen retention of Mashona cattle given different amounts of $\mathbf{N}$.

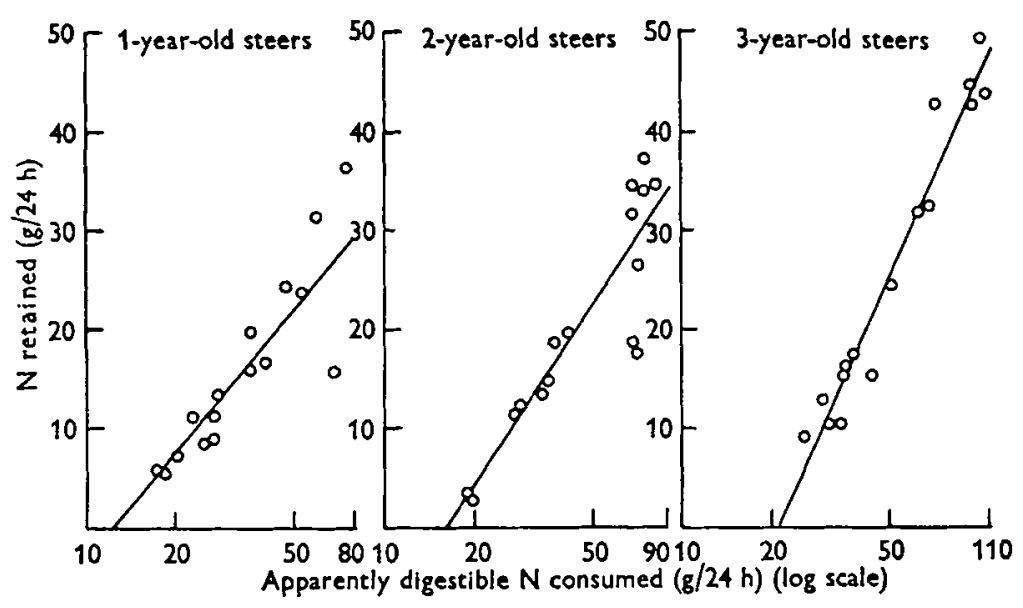

Fig. 2. Nitrogen retention of Africander cattle given different amounts of $N$.

$\mathrm{N}$ consumed. This relationship was not linear. A logarithmic transformation of the independent variable was calculated and gave a highly significant linear relationship $(P<0.001)$.

The findings are presented graphically in Figs. I and 2 and the computed regression lines for each breed and age group are given. Extrapolation of these lines to zero $\mathrm{N}$ retention provided an estimate of the mean digestible $\mathrm{N}$ required for $\mathrm{N}$ equilibrium. In this study $\mathrm{N}$ equilibrium is assumed to be synonymous with maintenance of body protein. These computed values are compared in Table 4 with those of Brody (1945) for animals of equivalent weights. 
For each group, the value obtained for the digestible $\mathrm{N}$ for maintenance was approximately one-third of that given by the Brody formula. If $\mathrm{N}$ losses in shed hair and skin excretions were taken into account, and the values previously calculated used, the digestible $\mathrm{N}$ required was increased by only $0.2-0.3 \mathrm{~g}$, depending on the size of the animal.

Table 4. Mean body-weights, mean apparently digestible nitrogen requirement for maintenance and calculated digestible $N$ requirement of groups of four steers

\begin{tabular}{|c|c|c|c|c|}
\hline Breed & $\begin{array}{c}\text { Age } \\
\text { (years) }\end{array}$ & $\begin{array}{c}\text { Body-weight } \\
(\mathrm{kg})\end{array}$ & $\begin{array}{c}\text { Digestible N } \\
\text { requirement } \\
(g / 24 h)\end{array}$ & $\begin{array}{c}\text { Calculated } \\
\text { digestible } N \\
\text { requirement } \\
\left(0.584 W_{\text {kg }}^{0.73}\right) * \\
(\mathrm{~g} / 24 \mathrm{~h})\end{array}$ \\
\hline Mashona & $\begin{array}{l}1 \\
2 \\
3\end{array}$ & $\begin{array}{l}243 \\
341 \\
394\end{array}$ & $\begin{array}{l}11.3 \\
12.3 \\
16.8\end{array}$ & $\begin{array}{l}32 \cdot 2 \\
41 \cdot 2 \\
45 \cdot 8\end{array}$ \\
\hline Africander & $\begin{array}{l}1 \\
2 \\
3\end{array}$ & $\begin{array}{c}284 \\
402 \\
484 \\
\text { - Brody (1945 }\end{array}$ & $\begin{array}{l}12 \cdot 1 \\
16 \cdot 2 \\
21 \cdot 0\end{array}$ & $\begin{array}{l}36 \cdot x \\
46 \cdot 5 \\
53 \cdot 3\end{array}$ \\
\hline
\end{tabular}

Table 5. Mean endogenous nitrogen output and mean apparently digestible $N$ requirement for maintenance of groups of four steers

\begin{tabular}{|c|c|c|c|c|}
\hline Breed & $\underset{\text { (years) }}{\text { Age }}$ & $\begin{array}{l}\text { Endogenous } N \\
\qquad(\mathrm{~g} / 24 \mathrm{~h})\end{array}$ & $\begin{array}{c}\text { Digestible N } \\
\text { requirement } \\
(\mathrm{g} / 24 \mathrm{~h})\end{array}$ & $\begin{array}{l}\text { Ratio, digestible } \\
\text { N:endogenous } N\end{array}$ \\
\hline Mashona & $\begin{array}{l}1 \\
2 \\
3\end{array}$ & $\begin{array}{l}3.91 \\
4.95 \\
4.96\end{array}$ & $\begin{array}{l}\mathrm{II} \cdot 3 \\
12 \cdot 3 \\
\mathrm{I} 6 \cdot 8\end{array}$ & $\begin{array}{l}2.90 \\
2.48 \\
3.39\end{array}$ \\
\hline Africander & $\begin{array}{l}1 \\
2 \\
3\end{array}$ & $\begin{array}{l}4.44 \\
5.06 \\
6.80\end{array}$ & $\begin{array}{l}12 \cdot 1 \\
16 \cdot 2 \\
21 \cdot 0\end{array}$ & $\begin{array}{l}2 \cdot 72 \\
3 \cdot 21 \\
3 \cdot 08\end{array}$ \\
\hline Mean & & & & $2 \cdot 96$ \\
\hline
\end{tabular}

The calculated digestible $\mathrm{N}$ requirements were closely related $(r=0.947)$ to metabolic body size. The calculated exponent was in fact 0.74 , but if the more generally accepted value of 0.73 is used the two factors were related by the equation $\mathrm{N}={ }_{197} W^{0.73}$ where $\mathrm{N}$ is the requirement in $\mathrm{mg} / 24 \mathrm{~h}$ and $W$ is in $\mathrm{kg}$.

Relationship between the maintenance requirement for apparently digestible $N$ and endogenous $N$ katabolism. Protein requirements for maintenance are frequently derived from the endogenous $\mathrm{N}$ output by multiplying this loss by a factor which allows for wastage in metabolism. In Table 5 the endogenous $\mathrm{N}$ outputs of the steers in the six breed-age groups, which have been previously reported (Elliott \& Topps, 1963), are compared with the estimated apparently digestible $\mathrm{N}$ requirements, and the corresponding ratio between the two values is also given. This ratio varied from I: 2.48 to $I: 3.39$ with a mean value of $I: 2.96$ for all groups. In comparison, Brody (1945) suggested that the maintenance requirement for apparently digestible $\mathrm{N}$ was four times the endogenous $\mathrm{N}$ output. 


\section{DISCUSSION}

When ruminants are given diets containing roughage ground into a meal and made into cubes, the voluntary intake of food is often found to increase. The high intake of the rations in our trials, particularly of those with a low protein content, is consistent with these observations. On the other hand, it is important to note that the amounts of food left uneaten by the steers were generally greater with the low-protein diets even though these diets contained large amounts of digestible carbohydrate and acceptable ingredients such as molasses and maize. It would appear that dry-food consumption is affected by the protein content of the diet irrespective of the other constituents present.

The mean true digestibility of the $\mathrm{N}$ in the diets was $75.6 \%$. This value and that for the metabolic faecal $\mathrm{N}$ excretion are both low when compared with the values calculated by Blaxter \& Mitchell (1948) for a variety of foods. No obvious reason for this difference can be deduced from the findings. It can only be tentatively suggested that cubing the diets increased their rate of passage through the digestive tract, lowering their true digestibility, and reducing the metabolic loss as digestive secretions and cellular detritus from the digestive tract.

The values obtained for the maintenance requirement for apparently digestible $\mathrm{N}$ have been compared with those proposed by Brody (1945). Brody's work was chosen for this comparison since it is the most comprehensive study of protein maintenance requirements so far reported. Further, most other standards for maintenance in practical use are either based on or are very close to the values advocated by Brody.

The large differences between the results obtained and the requirements advocated by Brody may be attributed to two factors. The endogenous $\mathrm{N}$ loss of the two breeds of cattle appears to be $50 \%$ or less of recognized values, which indicates that Brody's formula (endogenous $\mathrm{N}(\mathrm{mg})=146 W_{\mathrm{kg}}^{0.73}$ ) does not apply to the two indigenous breeds of cattle studied. Whether this finding means that these cattle have evolved some mechanism to reduce their endogenous $\mathrm{N}$ katabolism is not known. Although this explanation seems unlikely, it is consistent with the finding of Somers (x96I) that in sheep the return of urea to the rumen by the saliva is likely to be quantitatively important when the intake of $\mathrm{N}$ is low. The presence of the same or a similar mechanism in cattle could appreciably lower their endogenous $\mathrm{N}$ output. The second factor, to which the low $\mathrm{N}$ requirements for maintenance may be attributed, is the high efficiency of $\mathrm{N}$ utilization by the twenty-four steers when they were given the low-protein diet. Elliott \& Topps ( 1963 ) calculated a mean biological value of $82 \cdot 5 \pm 3^{\cdot 19}$ for the protein of the $5 \% \mathrm{CP}$ diet. Many authorities in calculating protein requirements for maintenance of ruminants have frequently assumed a biological value considerably lower. It is interesting to note that Smuts (1935) in calculating protein maintenance requirements used a biological value of 50 ; which gives a requirement of $0.35 \mathrm{lb}$ digestible protein for a $1000 \mathrm{lb}$ animal. If Smuts had used a biological value of 80 the corresponding requirement would have been $0.22 \mathrm{lb}$ which agrees with the low values obtained in our study.

The cause of the very efficient use of $N$ is suggested by the finding of Somers (1961), 
previously mentioned, and that of Chalmers \& Synge (1954). The latter showed that ruminal production of ammonia was low and that the $\mathrm{N}$ retention of the animal was greatly increased when the diet contained adequate amounts of available or readily fermentable carbohydrate. The diets used in the trials reported here had this characteristic. Further, energy-rich diets given to monogastric animals have a proteinsparing effect, which may operate also in ruminants.

In the determination of nutrient requirements by balance trials the question always arises as to how accurately the results apply in practice over a long period. With regard to protein it is frequently stated that optimum protein nutrition calls for a higher intake than the minimum required to maintain $\mathrm{N}$ equilibrium (Maynard \& Loosli, 1956). Reasons given for this difference relate mainly to variability of appetite, which is frequently poor on low-protein diets, and to fluctuations that may occur in the biological value of protein sources. If appetite is affected the animal may not consume adequate energy to maintain body functions and so its corresponding protein need may be greatly increased.

It would be unwise to assume that the protein requirements for maintenance calculated from the $\mathrm{N}$ balance trials reported here are adequate for keeping the same or similar animals in good condition without loss of weight or change in body composition over several months. However, it is unlikely that any discrepancy that may be found could account for the difference between the results of these trials and Brody's recommended protein requirement. Long-term feeding trials are clearly necessary to establish the validity of the results presented above.

\section{S UMMARY}

I. Nitrogen balance trials were made with cattle of two African breeds given four levels of protein. For each breed a total of twelve steers, aged I, 2 and 3 years, was used. Energy intake was adequate to support considerable weight gains.

2. There were no appreciable differences between the breeds in apparent digestibility of $\mathrm{N}$ and efficiency of $\mathrm{N}$ utilization.

3. All the animals were in positive $\mathrm{N}$ balance when the diets, which had crude protein contents of $5,7,9$ and $11 \%$, were given, which indicated that the cattle had a low maintenance requirement for protein.

4. The maintenance requirement of the steers for apparently digestible $\mathrm{N}$ in the six breed-age groups was approximately one-third of that advocated by Brody (1945) and of the value used in many feeding standards.

5. The daily requirement of the cattle for apparently digestible $\mathrm{N}$ was related to metabolic body size $\left(W^{0.73}\right)$ by the equation: $\mathrm{N}(\mathrm{mg})=197 W_{\mathrm{kg}}^{0.73}$.

6. The maintenance requirement for apparently digestible $\mathrm{N}$ was on average 2.96 times the endogenous $N$ output of the cattle.

7. The probable reasons for the low protein requirements for maintenance obtained and their applicability to field conditions over a long period are discussed. 
This work was supported by the Rockefeller Foundation. We acknowledge the co-operation of the Federal Ministry of Agriculture in providing facilities at the Henderson Research Station, the advice of Dr J. Oliver and the expert attention of Mr C. H. French and Mr I. Wedderspoon in the care and feeding of the cattle.

\section{REFERENCES}

Blaxter, K. L. (1959). In Scientific Principles of Feeding Farm Live Stock, p. 2 r. London: Farmer and Stock-Breeder Publications Ltd.

Blaxter, K. L. \& Mitchell, H. H. (1948). J. Anim. Sci. 7, 351.

Blaxter, K. L., Wainman, F. W. \& Wilson, R. S. (r96r). Anim. Prod. 3, 51.

Brody, S. (1945). Bioenergetics and Growth. New York: Reinhold Publishing Corp.

Chalmers, M. I. \& Synge, R. L. M. (1954). F. agric. Sci. 44, 263.

Elliott, R. C. (1963). F. agric. Sci. (In the Press.)

Elliott, R. C. \& Topps, J. H. (1963). Nature, Lond., I97, 668.

Mason, I. L. \& Maule, J. P. (1960). Tech. Commun. Bur. Anim. Br., Edinb., no. 14.

Maynard, L. A. \& Loosli, J. K. (1956). Animal Nutrition, 4th ed. New York: McGraw-Hill Book Company Inc.

Smuts, D. B. (1935). F. Nutr. 9, 403.

Somers, M. (1961). Aust. J. exp. Biol. med. Sci. 39, 145. 